UDC 316.6:37.017

Ernest GRIGORIAN

\title{
PROMOTION OF HEROIC CHARACTER AS SOCIAL SCIENCE AND EDUCATION TASK
}

\begin{abstract}
The article analyzes the catastrophic moods in some segments of Armenian society. This occurs due to the ongoing war, lack of faith in the future, loss of social orientation. The Armenian society does not feel care on the part of the ruling class, do not see its responsibility, feels helplessness in the face of external and internal threats, and, therefore, is in confrontation with the ruling class. And here is the new phenomenon of mass heroism of the people as a response to the catastrophic situation and reliance on heroes as saviors of the nation. Social science and education should more closely examine this phenomenon and try to make the heroism more meaningful and much full of sense.
\end{abstract}

Keywords: catastrophism, heroism, society, ruling class, education, social science.

Catastrophic Mentality as a

Fear of the Future

The modern world faces the growing level of military conflicts and crises, to which the world community has no means to answer. The main cause of the situation is that the response appears only when it's too late, when metastases of a crisis are already spread throughout the whole region or country. Late reactions cause the growth of the catastrophic mentality, which is based on the fear of the future. The future is perceived as a catastrophe. Fear, expectation of the negative events and processes that are likely to happen, play today an important and, in some cases, even a crucial role in public and global reality perception. It is a vicious circle: even in the absence of the visible traits of negative phenomena, catastrophic mentality projects the fears and creates the attitude. A major source of fear is information, which a person draws from cultural and social society institutions, especially from the media, educational institutions, art and literature, which are today full of false insinuations. Giant growth of the value of this information, its fundamental inclusiveness and global scale, especially when the computer networks and multichannel TV become an ordinary thing, the sophisticated potential impact of the modern mass media on the consumer - is the factor of the utmost importance for the growth of mass fears in modern societies.

Nowadays the vector of catastrophism has been steadily shifting from the fear of natural disasters to the fear of the mankind itself, the fear of those destructive forces concealed in an individual, within the organizations, institutions, communities, and the forc- 
es unleashed on the individual and group levels. The philosophy shifted to the reflections on the destructive beginning hidden in a human, in the depths of his personality. This trend finds its expression in a new humanistic and ecological worldview, which makes a person feel guilty about the environment and fear of his own destructive activity.

Let's look at the problem from the scientific point of view. The hypothesis of technohumanitarian balance has acquired more credibility in science. It states that with the strengthening of the new types of technological weapons and the emergence of the new threats to a society, the last responds by deploying and harnessing the new forms of social and human behavior, performing the function of protection against anthropogenic threats. The society inevitably is changing in response to these threats. There are new values and norms of behavior, institutions, and programs that prevent catastrophic trends. It happens not by itself, but as a result of the conscious and deliberate actions of groups of people who feel responsible for the future.

From the scientific point of view (the theory of complex non-equilibrium systems with non-linear laws of development, which represents the society), the world has created an unstable and paradoxical situation: the world is on the threshold of the transition phase, which is already visible to the naked eye. The laws of functioning of nonequilibrium systems are based on the principles of cyclicity and regularity. They state that the development of such systems takes place through a series of ups and downs, their disasters and outputs. In relation to the society, this means that the world will have to increase its sociogenous, humanitarian component as a reaction to the excessive development of the means of the armed violence.

Mental stability and anxiety of the population of Armenia, living in conditions of smoldering war and especially in potentially dangerous areas, is largely determined by the critical level of population density and the country's defensive capability. If this level is maintained and supported, a sense of security and confidence in the future of the region is high. Today this level is insufficient. The population of the RA is rising the representatives of catastrophism (Catastrophic mentality).

In addition, the international geopolitical environment, which is becoming more and more intense especially against migrants, including Armenians, contributes to the anxiety growth. Migrants, residing in a number of countries have become subjects to the pressure from the indigenous population of these countries, and this pressure increasingly takes on the color of religious nationalism. In these countries the growing atmosphere of anger is generated by the growing social polarization and the potential threat of inter-ethnic conflicts. However, this has become already a reality: such conflicts arise more and more often. Shortly, the situation became explosive, and the consequences can be disastrous on a large scale. All these processes clearly affect the mentality of the population of the Republic of Armenia. The media also creates a negative impact on the consciousness of the population.

The advanced part of the society is trying to develop a new philosophy of public (world) development that would allow rather than to avoid disaster, but at least to minimize losses. However, the demand for the new 
forms of the sociality is significant. At the same time, society in the midst of the major phase of the disaster will be more stable if its new meanings will have to rely on some continuity with the past. Among those principles and regulations, which will have to be updated in the frames of the socio-humanitarian ideology, and which seems to be useful and important pillars of the society are the rule of law, the doctrine of human rights, democratization of public life etc. But, alas... Even if they are looked through a prism of new knowledge and, consequently, receive the new content, they are insufficient in the time of military conflicts and crises.

The world community has no major holistic project of deploying such human viability, where each person would have his role or even more, would become a constructive element in this project. In the absence of such project people do not need each other, and therefore, the concepts of the overpopulation of the planet are born, mutual destructive wars are multiplying. But where is perdition, there is also salvation.

The social system can be considered as a self-organized and vibrant integrity where the stable phases in the development are periodically replaced by the catastrophes. One of the essential features of this system, in contrast to the natural life, is the fact that the human community can regulate these processes himself. It needs quite another thing.

\section{The Birth of a Hero}

In these times society needs a strong powerful heroic leader to establish stable long lasting peace in the world. These leaders who serve as a model to people show the way out of the blind alley of selfishness, hatred and greed. Up to now neither science nor education has paid any serious attention to seeking or bringing up such leaders or even studying the conditions of their appearance. Today the world is craving for renovations. But only heroic strong-willed personalities can change rotten living conditions of people.

Modern ruling classes of many societies, including Armenia, are where hypocrisy and market relations have full reign. They always strive for full permanent control over the process of the public consumption and consequently over the consumers themselves. They need totally controlled individuals living according to "the law of consumption" and not asking questions about the rules and guidelines, they need people of the same shape, the puppets, who put material above all in every situation. Similar modern materialistic society of mass consumption is pagan in itself. But this society is a dream and goal for modern ruling classes. They are being known as more pagan as traditional pagan cultures, worshiping only few objects - the Golden calf and pleasure.

They want that every object designated for consumption would become the special icon and therefore turn into a specific object of worshiping i.e. consciously or unconsciously become deify. Science or TV shows, cars and new movies, art or country house, film stars and detergents, sportsmen and fashion houses, the latest model of vacuum cleaner and bestseller, a football team, a new model of a mobile phone, ideological slogan, and an aluminum can of beer and so on can become icons for different social groups. But money and people's bodies are on the top of this huge pantheon. "Their consumer's socie- 
ty" is not and do not need to accept anything heroic at principle. That is because the "heroism" is the triumphant demonstration of the immortality of spirit over the temporal illusion of the body.

Ruling classes of Armenia rely on modern western overwhelming paganism, which states that any object of consumption is an icon, capable of making quasi- miracles. It means that somewhere deep inside the paganism there is a permanent tentative of the turning an object-icon into a "hero", deceitful hero and this is done by means of a constant desacralisation of a person, turning him into unspiritual creature. That is why a true hero is not only useless in such society, and, moreover, he is dangerous, very dangerous for these ruling classes. They are afraid of true heroism in the society as they try to suppress real cult of heroes. Instead there is a carefully planned process of turning heroism into a bureaucracy. There is a whole industry of mass production of virtual heroes, quasi-heroes, and false images. The society of mass production and mass consumption is based on the prediction and the frame of mind of millions of tame people. But a hero is not under control when in action, because the heroism is first of all a special, mysterious form of consciousness and only then the heroic action is the event.

But Armenian people, despite their ruling class's desire, continue to create real heroes. And at the same time of catastrophism they need these heroes. Every person deep in his heart longs for the divine light, the unknown expectation of something unusual, unexpected, the yearn for long-lasting strive for heroism like a faraway cry of the buried but still free and alive soul.

Heroism is creative not in the narrow sense of this word, but also in the sense of the creation the "stream of life." The Hero by the definition is the person who breaks the frames of the conventional routine, who kills profanity by his existence, who becomes the creative example not only in space but also in time. But the ruling class needs the stability of senseless boredom and hoarding, not the active creative mind, indefinite one. But what is more important is that on their principle there couldn't be any heroism as a phenomenon. There dominate only miserable little men, obsessed by the passion for accumulation, living from one attempt of intercourse to another, who call "terrorist" anyone who doesn't allow to destroy his faith, his people, human dignity.

The paradox of the Armenian society is that it is living, while his ruling class is dying out. The paradox is that the society, who is full of fear of future begets (gives birth) the heroes that put an aim to escape societies' death, at the cost of his/her own life. While the ruling class founds itself in the complete power of Tanatos complex. The will power in this society is so great that people are able to give birth and bring up their offsprings more and more for the salvation of society. They know that hundreds and thousands of tribes, folks and peoples vanished just because they lost their will power that was accumulated and showed up first of all in millions of heroes.

The societies that came through such ordeals are traditional ones. People in these societies are not only law-abiding, they live according to the more deep rules and regulations, they live by the law of history and memories.

The phenomenon of real heroism is very 
important for the existence of such society. The appearance and existence of real heroes who deliver God's will and intentions and who become models and examples for millions of people are very important.

This acting like heroes is not just constant Philistine worship but overcoming and fighting all the profane sick and illusive in a man. It is also the returning to the perception and recognition of life of one person, a group of people and the society, which is unusual. It is returning to the recognition of the essence of living and a deep thought of being the part of a total space unity.

If something heroic appears and begins to grow in the society, and this society gives rise to heroes, it means that God cares for this society, it also means that we can feel God's good will for anything heroic in this society.

Acting like a hero is not only doing one's duty for the sake of God but it's also the ability of a spiritual development of a person. Acting like a hero then becomes not only the necessary social but also the personal creative action.

In the long run only the societies where heroes are born survive.

Some societies where there is a little minimum of heroism still keep track in history. And consequently the societies where heroes are not born (because there is no need in them) sooner or later disappear. This sign from above means: such societies make God angry.

"A human being is somebody who has to overcome" (Nitshe, 2005). Frederic Nitshe emphasized this radical opposition between the heroic and profane in a man. Eight hundred years before Nitshe a very prominent Islam thinker Abu Hamid al-Ghazali consid- ered this overcoming not only the order from above, but the essence of a human life. "The meaning of happiness is the battle with yourself, overcoming yourself in every way, the most you can, though the steps to perfection are endless" (Al-Ghazali, 2002).

There is something direct uncompromising and at the same time the most respectful in the clash of a human spirit and death, when the spirit breaks through the light and dark sides of a powerful death. At that moment the great death suddenly becomes the decisive ordeal, the whole previous life of a man was the preparation to it.

"Live so as if you'll never die. And get ready for death as if you're going to die tomorrow".

The legendary Roman Mootsi Stsevola kept his right hand in a flame of a fire talking to the leader of the invaders in his Motherland. He demonstrated not only his contempt to death, to the physical pain, he demonstrated the will power and the bravery of a warrior, the strength of a real man. He was the courage itself turning into the heroic spirit.

The same trait is peculiar to the Christ: the most important is his contempt to death. His well-known phrase "If you're hit in the right cheek, give the left one for the hit" makes a challenge to any attempts to frighten, to impose fear upon physical pain causing by enemies. There is a parallel to Mootsi Stsevola in this fearfulness and contempt to the foes, the mockery of their threats. The official or false praise sometimes changes the image of heroism in the most radical way and Jesus Christ is an example. Nevertheless the core of heroism remains unchangeable. The most important in the heroic deed is first of all the unusual personal energetic impulse in a certain 
place at a certain time but not the instant efficiency. Heroism is more spiritual powerful effort than physical.

Heroism is a deep fragile intuition that causes the complete responsibility of the cruel strategies and harnesses their arrogance.

Take for example another Christ's saying - "Love your enemies". It can be interpreted as the samurai warrior's code "Bushido". First of all the soldier has to know his enemies very well, study their nature, customs, habits, their way of military thinking. Moreover a good warrior has to know how to rule the enemy as his own army and generally consider the enemy as a part of his own army being at his disposal as an additional resource. This is nothing but metaphorical expression of love to the enemy.

The hero as an example to follow is the real hero not only in a social aspect but also in a social context. The example of heroism has a very important sacred meaning. The way of conscious neglecting profane, the way to the spiritual immortality, the way to God always requires such personal great overpowering effort, such heroism when it becomes organically natural as breathing.

The vivid example of a spiritual heroism is the deepest recognition of tradition where the hero capable to commit the overpowering effort is taken care of by God. What the hero commits is a real miracle in which God's holly intention is reflected.

Heroes are born in such societies where the spirit (in spite of everything) continues to fight the self-satisfied stuff, where the true faith dominates other values and where God inspired truth (exactly people's religious faith) is above life. But if people's greed, selfinterest and hypocrisy propagated by mass media rule the society, it cannot generate heroes.

Heroism is a compound integrity of the four components.

1. The will power of the personality. Strong will of the personality is exactly unique for the definite place and the definite time. And this will show up only through the special mature conscience of a person, his personal way of thinking. The maturity of a thinking person is shown by the degree of his readiness to give his life for his ideals and beliefs. But if the person is not ready to give his life for his ideals it means that either his ideals are worth of nothing or the person himself is worthless.

2. Social responsibility is the utmost dramatic strain of one or the several social values connected with the deepest crisis of a certain society or with the challenge to this society. Sometimes it may be connected with a dramatic aggravation of the problem of survival (external aggression, special home crisis, the civil war, global catastrophe and so on).

3. Leadership as a relay race. Leaders do not run from dangers but are subjected to them together with all people. They die together with the people and win victory with them. And if people see that their leaders do not hide behind their backs but lead the way and die for the benefit of their country and people, these leaders are deeply honored, loved, praised and respected by their countrymen. They get everything from them, including life. But it only becomes possible when people trust and truly believe in their leaders.

But without such hero-leaders there 
can't be heroic people who can fight for the liberty and justice for all. And if the leader sows the seeds of dictatorship in his organization, he saws the seeds of destruction in it.

4. The nobility and generosity are a privilege of a strong people. These qualities crown the self-development of a higher product of evolution but, regrettably, they are unknown to many modern societies, where miserable men dominate. Only they can beat defenseless, kill helpless. Only they as beast flock hit upon one, they seem weak.

Social science and education face the eternal problem of raising and supporting everything heroic. They must to make the hero- ism more meaningful and much full of sense. The mysticism of history circulates: the societies without heroes are replaced by those where there's a lot of heroic breed, where faithfulness to the heroic spirit, to the eternity is cherished. This is how the society becomes heroic itself.

\section{REFERENCES}

Al-Ghazali, A. H. (2002). The Incoherence of the Philosophers (2nd. ed.). (M.E. Maarmura, Trans.) Brigham Young UP. ISBN 0-8425-2466-5.

Nitshe, F. (2005). Thus Spoke Zarathustra. (G. Parkes, Trans.) Oxford: Oxford World's Classics. 